\title{
Composition Studies on Tobacco
}

\section{Use of Clgarette Additives to Alter the Composition and Reducing Propertles of Cigarette Smoke*}

\author{
by L. Lakritz, E. D. Strange, D. G. Bailey and R. L. Stedman
}

Eastern Marketing and Nutrition Research Division,

United States Department of Agriculture, Philadelphia, Pa:, USA

Until recently, interest in the reducing properties of cigarette smoke was based on the desire to develop an analytical technique to determine tobacco leaf quality. In 1962 Wickham et al. (12) developed an automated colorimetric procedure to determine the quantity of reducing substances in smoke. He was able to demonstrate that the amount of reducing substances in cigarette smoke varied with the variety, quality and stalk position of the tobacco leaf used in the fabrication of the cigarette.

Hagopian (6) devised a more rapid procedure for determining the level of reducing substances in smoke using blue tetrazolium dye. He reported that more than $90 \%$ of the reducing substances in whole smoke was in the particulate phase. Using this technique, Hagopian and Rosenkrantz (7) found that 80 to $95 \%$ of these reducing substances was retained in smokers' lungs. Benedict et al. (3) also found that the major portion of the reducing substances in whole smoke was located in the particulate phase; in addition, using the redox dyes 2,6-dichlorophenol, -indophenol, toluylene blue and blue tetrazolium, they determined that the reducing potential of cigarette smoke was in the range of 120 to 200 millivolts.

In the investigation by Benedict et al. (3), measurement of the reducing properties of the smoke was made subsequent to the collection of the smoke. Rapid changes occurring during smoking or in the interval between collection and measurement would therefore not be detected using previously described procedures. In thepresent report we have employed a method which overcomes this problem by continuously monitoring the change in redox potential from the first puff to the completion of the experiment; details of the method will be reported elsewhere (8). Using this technique we obtained redox profiles from the smoke of commercial cigarettes and compared them to profiles obtained from the same cigarettes impregnated with various oxidizing and reducing substances. The effect of these oxidizing and reducing agents on the levels of benzo(a)pyrene, nicotine, pheriols and total particulate matter in whole smoke was also investigated.

\footnotetext{
- Received for publication: 18th March, 1971.
}

\section{MATERIALS AND METHODS}

\section{Preparation of Cigarettes Containing Additives}

Commercial non-filter $85 \mathrm{~mm}$ American cigarettes were used in all experiments. Generally, additives were dissolved in a suitable solvent and an appropriate quantity was then injected lengthwise into the individual cigarettes using a syringe. In one case (Brown's reagent) the solid additive was handled differently (vide infra). All cigarettes were stored in a desiccator over a $76 \%$ glycerol in water solution for at least 48 hours before smoking. The additives used were as follows:

Benzoquinone - $100 \mathrm{mg} /$ cigarette (dissolved in acetone),

Hydrogen peroxide - $14 \mathrm{mg} /$ cigarette,

Benzoyl peroxide - $66 \mathrm{mg} /$ cigarette (dissolved in chloroform),

Sodium thiosulfate $-70 \mathrm{mg} /$ cigarette (dissolved in water),

Ferrous chloride $-64 \mathrm{mg} /$ cigarette (dissolved in water),

Brown's reagent (4) - (100 mg of catalyst/ cigarette) - reagent was mixed with tobacco and these cigarettes were hand-fabricated.

\section{Measurement of Reduction Potential}

Cigarettes were smoked on a Mason Smoking Machine** at a rate of one $35 \mathrm{ml}$ puff of two-second duration per minute. Each cigarette was smoked down to a $28 \mathrm{~mm}$ butt length. Whole smoke was passed from the cigarette through Tygon tubing to a reaction vessel (approximate volume $20 \mathrm{ml}$ ) and was bubbled through $15 \mathrm{ml}$ of $0.1 \mathrm{M}$ phosphate buffer $\mathrm{pH} 7.0$ therein. The vessel contained two electrodes. A platinum electrode with a silversilver chloride half cell was used to measure electrometric changes. A combination hydrogen ion electrode was used to measure $\mathrm{pH}$. A separate $\mathrm{pH}$ meter was used with each electrode pair and the changes in EMF and $\mathrm{pH}$

* Mention of commercial items does not imply their endorsement by the Department over similar products not mentioned. 
were recorded on a dual pen recorder throughout the experiment.

For each redox determination a single cigarette was smoked down to the $28 \mathrm{~mm}$ butt length, the cigarette was removed and nitrogen was bubbled through the vessel to prevent air oxidation of the smoke solution. Measurements of the electrometric potential and of $\mathrm{pH}$ were recorded for a total of $45 \mathrm{~min}$., after which time the experiment was terminated.

\section{Nicotine and Phenol Determination}

Five cigarettes were smoked on a Mason Smoking Machine under the previously described conditions. The smoke was passed through a Cambridge filter and the vapor phase was scrubbed by a trap containing $25 \mathrm{ml}$ of $1 \mathrm{~N}$ sulfuric acid. After completion of smoking, the filter pad was macerated in $20 \mathrm{ml}$ of acetone. The acetone suspension was transferred to a $250 \mathrm{ml}$ distilling flask and the $25 \mathrm{ml}$ of $1 \mathrm{~N}$ sulfuric acid from the trap was added. Two hundred mls of steam distillate were collected and set aside for phenol analysis. Phenols were determined colorimetrically by reaction with diazotized p-nitroanaline as described by Smith and King (9). Twenty-five $\mathrm{ml}$ of $30 \% \mathrm{NaOH}$ saturated with $\mathrm{NaCl}$ were added to the distilling flask and an additional $140 \mathrm{ml}$ of steam distillate collected in a receiver containing to $\mathrm{ml}$ of phosphate buffer $\mathrm{pH}$ 6.5. Nicotine was determined in this fraction by the colorimetric analysis of Asmus et al. $(1,2)$ with two modifications. The volumes of the reagents and sample solutions were reduced to one fourth and a complete spectrum (350 to $700 \mathrm{~nm}$ ) was run using a $1 \mathrm{~cm}$ cuvette. Calibration curves of concentration of nicotine vs. absorption at $510 \mathrm{~nm}$ were obtained daily and used to calculate the amount of alkaloid present.

\section{Benzo(a)pyrene Analysis}

Sixteen cigarettes, in groups of 5, 5 and 6, were smoked on the Mason Smoking Machine. The smoke was collected in a trapping system consisting of two cold finger traps immersed in dry ice-acetone followed by a Cambridge filter.

The traps and filter were washed with acetone to remove the condensate. Tritiated benzo(a)pyrene (BAP) was added to the solution of condensate as an internal standard. The condensate was fractionated by liquid partitioning, silica gel column chromatography and paper chromatography. The zone containing BAP was eluted from the paper with methanol, and after concentration, the BAP in the remaining solution was quantitated fluorimetrically as described by Davis et al. (5). The level of tritium in the final solution was used to correct for losses of BAP which occurred during the isolation.

\section{Total Particulate Matter (TPM) Determination}

TPM was determined by smoking five cigarettes, passing the smoke through a Cambridge filter, and weighing the filter immediately thereafter.

\section{RESULTS AND DISCUSSION}

The reducing properties of untreated commercial nonfilter $85 \mathrm{~mm}$ cigarette smoke are presented in Figure 1. This figure clearly demonstrates the rapid decrease in reduction potential which takes place within the first six puffs. From this point until the cessation of smoking there is only a slight additional decrease in reduction potential. Immediately after the final puff (9 minutes) there is a small increase in the potential. Since the solution is placed under nitrogen immediately following the last puff it is unlikely that this increase is due to air oxidation. It appears that there is an equilibrium established between the oxidants and reductants in the smoke. Once the potential levels off (within $20 \mathrm{~min}$.) it continues to be stable for several days with a slight minor drift toward an increased potential.

The results obtained with untreated cigarettes were compared with the redox curves obtained by smoking cigarettes impregnated with various oxidants and reductants.

In the first series of experiments three oxidants were used, hydrogen peroxide, benzoyl peroxide and benzoquinone. The addition of the peroxides to the cigarettes had no effect on the reducing capacity of smoke. It is likely that both of these compounds were decomposed either upon addition to the tobacco or during the burning process. The addition of the third oxidant, 1,4-benzoquinone, prevented the significant decrease in potential observed in the control (figure). After a very small drop in potential during smoking of the cigarette the potential then returns to the original level and thereafter slowly decreases. This is probably due to the transfer of small quantities of benzoguinone into the smoke and its subsequent reduction to hydroquinone.

Figure 1. Reduction characteriatice for an untreated commerclal cigarette (control), cigarette containing $100 \mathrm{mg}$ of benzoquinone and clgarette containing $70 \mathrm{mg}$ of sodlum thiosulfate.

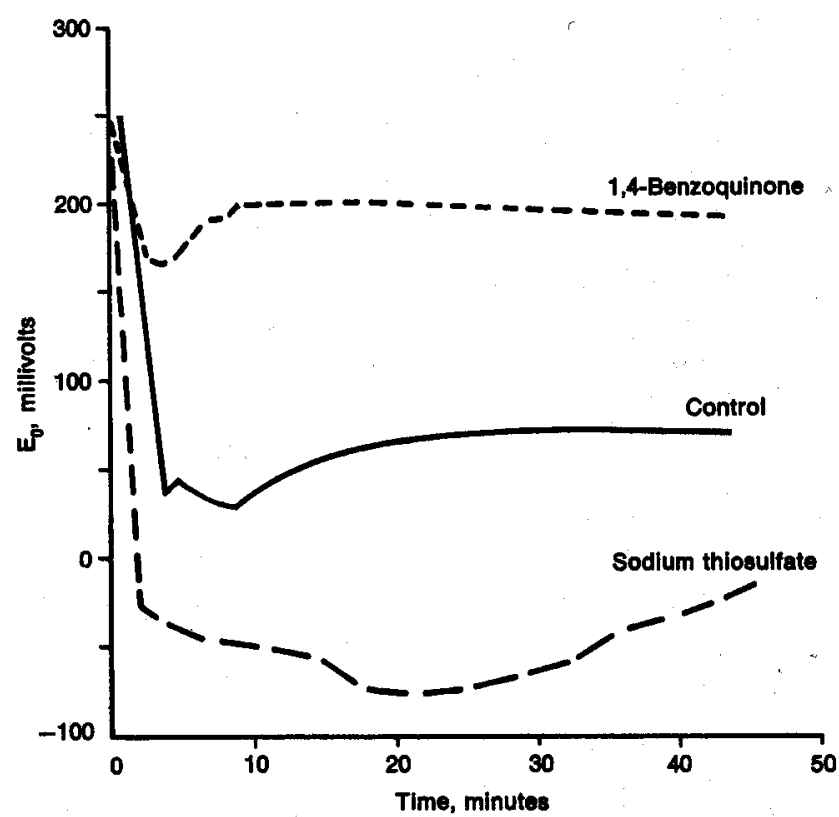


The reductants used as additives were Brown's reagent, ferrous chloride and sodium thiosulfate. The cigarettes treated with Brown's reagent (4), which is a mixture of chloroplatinic acid and sodium borohydride deposited on charcoal, did not exhibit a decrease in potential as expected. The presence of charcoal in the reagent may have removed by absorption some reducing substances in the vapor phase prior to passing into the buffer. This could account for the unexpected overall increase in the observed potential. Ferrous chloride treated cigarettes burned poorly and required approximately $1-1 / 2$ times as long to burn to the standard butt length. It slightly decreased the final potential attained during smoking, but more significantly, it prevented reoxidation after the final puff. Sodium thiosulfate (figure) also caused the cigarette to burn poorly and required almost twice as long as the control to reach the standard butt length. The use of this reductant significantly lowered the redox potential, although reoxidation started as soon as smoking stopped and continued to the end of the experiment without levelling off. This may have been due to release of oxygen by the thiosulfate during smoking; with some of the oxygen going over into the smoke and causing oxidation in the smoke solution in the later phases of the readings, i.e. after about 25 minutes (figure).

The effect of the added benzoquinone and sodium thiosulfate on TPM, total phenols, nicotine and BAP was examined (Table $\mathrm{I}$ ). Cigarettes treated with $100 \mathrm{mg}$ of 1,4-benzoguinone caused increases in TPM and phenols, a decrease in the nicotine level and no significant change in the benzo(a)pyrene content from whole cigarette smoke. The increase in the TPM is probably due to the physical transport of the additive during smoking. Benzoquinone sublimes when heated, and a flaky grayish-black substance, apparently the additive, can be seen collecting in the dry ice traps and upon the Cambridge filters. The $21 \%$ increase in the level of phenols is also in all likelihood due to the measurement of the reduced form of the additive, hydroquinone (the colorimetric procedure employed measures all of the major smoke phenols). The possibility of a higher burn temperature caused by the presence of oxygen from the additive could be responsible for lower levels of nicotine due to greater pyrolytic fragmentation of nicotine to such products as 3-methylpyridine, 3-vinylpyridine and pyridine (10). The addition of benzoquinone had no significant effect on the level of benzo(a)pyrene.

Table 1. Effect of clgarette additives that alter smoke redox or smoke composition.

\begin{tabular}{l|c|c|c}
\hline \multicolumn{1}{c|}{ Constituent } & None & $\begin{array}{c}\text { Additive } \\
\text { 1,4-Benzo- } \\
\text { quinone }\end{array}$ & $\begin{array}{c}\text { Sodium } \\
\text { thiosulfate }\end{array}$ \\
\hline TPM (mg/cig.) & 22.9 & 29.1 & 25.2 \\
BAP ( $\mu$ g/cig.) & .067 & .071 & .096 \\
Nicotine (mg/cig.) & 1.97 & 1.54 & 1.31 \\
Phenol ( $\mu$ g/cig.) & 220 & 266 & 299 \\
Average no. of puffs & 9 & 10 & 18 \\
\hline
\end{tabular}

Cigarettes that were treated with $70 \mathrm{mg}$ of sodium thiosulfate showed increases in TPM, phenol and BAP but the level of nicotine was decreased. The increase in TPM may be due to the deposition of free sulfur from the decomposition of sodium thiosulfate. Lower levels of nicotine may also be related to the oxidation of the additive to sulfurous and sulfuric acids; these acids could possibly bind. the alkaloid as a nonvolatile relatively stable salt and thereby alter the basic kinetics of nicotine pyrolysis (II). The use of sodium thiosulfate may significantly enhance the reducing atmosphere found in the burning cone. Free radical formation is enhanced by a reducing atmosphere and the increase in free radicals may have resulted in the increased formation of BAP. A possible mechanism for the increase in phenols cannot be offered at the present time.

\section{SUMMARY}

The reducing potential of fresh cigarette smoke can be modified by the use of certain oxidants and reductants. The influence of these additives on smoke may be monitored by employing a system which measures changes in EMF on a puff by puff basis. The addition of the oxidant 1,4-benzoquinone to tobacco eliminates the rapid reduction in potential which normally takes place when an untreated cigarette is smoked. The addition of the benzoquinone alters the composition of the smoke by increasing the levels of the total particulate matter and possibly the phenols, while decreasing the nicotine content without affecting the amount of benzo(a)pyrene formed.

The addition of sodium thiosulfate to tobacco causes a significant increase in the reducing capacity of cigarette smoke. It also brings about increases in the smoke BAP, phenols and TPM. The level of nicotine in these cigarettes, however, is lowered.

\section{- ZUSAMMENFASSUNG}

Das Reduktionspotential frischen Cigarettenrauches kann durch bestimmte Oxydations- oder Reduktionsmittel verändert werden. Die Wirkung dieser Additive auf den Rauch kann mit Hilfe einer Meßanordnung kontrolliert werden, die zugweise Veränderungen der EMK bestimmt. Der Zusatz des Oxydationsmittels 1,4-Benzochinon zum Tabak hebt die schnelle Abnahme des Reduktionspotentials auf, die normalerweise beim Rauchen einer unbehandelten Cigarette stattfindet. Ein Zusatz der genannten Verbindung ändert die Zusammensetzung des Rauches; die Menge an Gesamtkondensat, möglicherweise auch an Phenolen, wird erhöht, während der Nikotingehalt abnimmt. Die Bildung von Benzo(a)pyren wird nicht beeinflußt.

Der Zusatz von Natriumthiosulfat zu Cigarettentabak bewirkt eine signifikante Zunahme der Reduzierfähigkeit von Cigarettenrauch. Außerdem erhöht sich dadurch auch der Gehalt an Benzo(a)pyren, an Phenolen und an Gesamtkondensat; das Nikotin im Rauch nimmt dagegen ab. 


\section{RESUME}

Certains oxidants et réducteurs ont le pouvoir de modifier le potentiel de réduction de la fumée fraîche de cigarettes. On peut déceler l'influence de ces additifs sur la fumée en employant un système qui mesure les variations d'EMF d'une bouffée à l'autre. L'addition au tabac de l'oxidant 1,4 -benzoquinone élimine la réduction rapide de potentiel, qui a normalement lieu lorsqu'on fume une cigarette non traitée. L'addition du benzoquinone altère la composition de la fumée en augmentant les niveaux de la phase particulaire totale et peut-être des phénols, et en diminuant la quantité de benzo(a)pyrène formé.

L'addition de thiosulfate de sodium au tabac provoque une augmentation significative de la capacité réductrice de la fumée de cigarette. Il augmente de façon marginale le taux de BAP, des phénols et de la phase particulaire totale dans la fumée, et abaisse le taux de nicotine.

\section{REFERENCES}

1. Asmus, E., Hohne, R., and Kraetsch, J.: Z. Anal. Chem. 187 (1962) 33.
2. Asmus, E., and Papenfuss, D.: Ibid. 185 (1962) 201.

3. Benedict,..R. C., Lakritz, L., Strange, E. D., and Stedman, R. L.: Chem. \& Ind. 1970, 800.

4. Brown, H. C., and Brown, C. A.: J.A.C.S. 84 (1962) 2827.

5. Davis, J. E., Lee, L. A., and Davidson, T. R.: Anal. Chem. 38 (1966) 1752.

6. Hagopian, M.: Environmental Sci. Technol. 3 (1969) 567.

7. Hagopian, M., and Rosenkrantz, H.: Proc. Soc. exptl. Biol. Med. 130 (1969) 1234.

8. Lakritz, L., and Benedict, R. C.: In preparation.

9. Smith, G. A. L., and King, D. A.: Analyst 89 (1964) 305.

10. Stedman, R. L.: Chem. Rev, 68 (1968) 153.

xx. Stedman, R. L., Lakritz, L., and Strange, E. D.: Beitr. Tabakforsch. 5 (x969) I3.

12. Wickham, J. E., Westbrook, J. J., and Holmes, J. C.: Tobacco Science 6 (1962) 50.

The authors' address:

US Department of Agriculture, Eastern Marketing and Nutrition Researd Division, 600 East Mermaid Lane, Philadelphia, Pennsylvania, 19118, USA. 